\title{
Relevance of Forensic Accounting in the Detection and Prevention of Fraud in Nigeria
}

\author{
Olukowade Eliezer $^{1 *} \quad$ Balogun Emmanuel $^{1.2}$ \\ 1. Department of Accounting, The Federal Polytechnic, Ado - Ekiti \\ P.M.B. 5351,Ado - Ekiti, Ekiti State, Nigeria. \\ 2. Department of Accounting, The Federal Polytechnic, Ado - Ekiti \\ P.M.B. 5351,Ado - Ekiti, Ekiti State, Nigeria.
}

\begin{abstract}
The increase in the number of cases of financial fraud due to failure of statutory audit to detect and prevent fraudulent activities has given rise for the services of forensic accountants. This paper highlights how forensic accountants can be employed to resolve this challenge. The study was a theoretical research which considered the roles of forensic accountants in combating fraudulent activities, differences between a forensic accountant and traditional accountant, features of a forensic accountant and the impact of forensic accountants to detect and prevent fraud. From the research, it was found out amongst others that their services will assist audit committee members in carrying out their oversight functions by providing them assurance on internal audit report. Some of the recommendations proffered is for government to ameliorate the cost of hiring the services of forensic accountants and to treat culprits equally without any favoritism.
\end{abstract}

Keywords: Forensic Accountant, Financial Fraud, Statutory Audit, Fraud Prevention, Fraud Detection.

\section{Introduction}

Forensic accounting is the specialty area of the accountancy profession which describes engagements that result from actual or anticipated disputes or litigation. "forensic" means "suitable for use in a court of law", and it is to that standard and potential outcome that forensic accountants generally have to work (Crumbley, Heitger, and Smith, 2005). Forensic accounting can also be seen as an aspect of accounting that is suitable for legal review and offering the highest level of assurance (Apostolou, Hassell, and Webber, 2000). The unrelenting series of embarrassing audit failures over the last 52 years has prompted a paradigm shift in accounting. Interestingly, in the mid - 20th century, when the flight from fraud detection was at its height, a few observers predicted that in the future there will be acceptance of the general responsibility of the auditor to perform tests to detect material defalcations and errors if they exist (Brown, 1962).

Forensic accounting is perceived to have evolved in response to certain emerging fraud related cases. The scandals that recently rocked the corporate world with classical examples being the often cited Enron and WorldCom cases have also brought the field of forensic accounting to the forefront.

Forensic accounting is seen as encapsulating all other investigation related areas in uncovering financial fraud. The increasing sophistication of financial fraud requires that forensic accounting be added to the tools necessary to bring about the successful investigation and presentation of those individuals involved in criminal activities (Moduga and Anyaduba, 2013). The general expectation is that forensic accounting may offer some respite to the seemingly vulnerability of conventional accounting and audit systems to financial fraud.

\section{Review of Literature}

The term forensic accounting is credited to Maurice E. Peloubet. In the late 1940s, forensic accounting had become popular during World War II, but major academic studies in the field were published in the 1980s (Rasey, 2009). Thus, a new profession emerged in the field of accounting in the 1980s with interest from western countries and especially in the USA. This new profession identifies fields comprising accounting, auditing and investigative skills (Ozkul and Pamuke, 2012).

According to Singleton and Singleton (2010), forensic accounting dates back to the days of pharaoh in Egypt as his eyes and ears were people who watched over his inventories of grain, gold and other assets.

Also they view forensic accounting to comprise fraud investigation, prevention of fraud and analysis of antifraud controls in addition to gathering non financial information.

However, forensic accounting according to Crumbley (2003) involves forensic science which may be defined as application of the laws of nature to the laws of man. He opined that forensic scientists as examiners and interpreters of evidence and facts in legal cases also offer expert opinion concerning their findings in a court of law. The science in question is accounting science meaning that examination and interpretation carried out will be for economic information.

Forensic accountants calculate values draw conclusions and identify irregular patterns or suspicious transaction by analyzing financial datas (Arokiasamy and Cristal, 2009). The job of a forensic accountant amongst it others includes identifying perpetrators of fraud, tracing money laundering and theft activities 
including tax evasion hire forensic accountants to detect insurance frauds such as arson, and law offices employ forensic accountants to identify marital assets in divorce cases (Weygandt, Kieso, and Kimmel, 2008).

Whether a professional is evaluating a business for bankruptcy, conducting an insurance investigation, searching for hidden assets in a divorce proceeding, or investigating the revenue recognition procedures of a publicly quoted company, the fear of fraud is the motivation for hiring the forensic accountant and he is expected to detect fraud where it exist (Gray and Moussalli, 2006).

\section{Fraud Detection}

Okafor (2004) reported that fraud is a generic term and embraces all the multifarious means which human ingenuity can devise, and resorted to by an individual to get advantage over another in false representation.

According to Anyanwu (1993), fraud is an act or course of deception, deliberately practiced to gain unlawful or unfair advantage; at the detriment of another.

Karwai, (2002); Ajie and Ezi, (2002); Anyanwu, (1993); Okafor, (2004) and Adeniji, (2004) Summarize the types of fraud on the basis of methods of perpetration which includes the following but not exhaustive: defalcation, suppression, outright theft and embezzlement, tampering with reserves, inside abuses and forgeries, fraudulent substitutions, unauthorized lendings, lending to ghost borrowers, kite flying and cross firing, unofficial borrowing, impersonation, fake payment, fraudulent use of the firms documents, fictitious accounts, false proceeds of collection, manipulation of vouchers, dry posting, over invoicing, inflation of statistical data, ledger accounts manipulation, fictitious contracts, duplication cheque books, computer fraud, misuse of suspense accounts, false declaration of cash shortages etc. It has been analysed that three components come to bear when committing fraud. These components which are pressure, opportunity and justification constitute the fraud triangle. Pressure factors could be categorized into three groups: pressures with financial content, pressures steaming from bad habits and pressures related with job.

Opportunity factor is the second component of the fraud triangle. It directly involves top management and owners of the business in particular. Providing the opportunity to commit fraud is one of the most important factors arising from frauds. The third component of the fraud triangle is fraudster's developing defence mechanisms in order to justify their action (Enofe, Okpako, and Atube, 2013).Over time, increase in the events of fraudulent acts has led to great importance attached to the initial detection of fraud (Enofe, Okpako and Atube, 2013).There are two main ways to detect frauds: (a) detection by chance and (b) conducting a proactive research and encouraging initial identification of symptoms, (Enofe, Okpako, and Atube, 2013). Fraud is costly as an estimated \$3.5 trillion worldwide has been lost due to fraudulent financial statements, asset misappropriation, and corruption (ACFE, 2012). As a result, Accounting standard setters have increased the steps auditors are expected to take in order to detect fraud which ultimately should restore public trust in the audit profession. However, identifying the occurrence of the cases of fraud is very difficult (Karwai, 2002). According to (Karwai,2002), frauds perpetrated by organizations in modern day usually involve complex web of conspiracy and deception that often mask the actual cause. Fraud in whatever nature and guise, has to be detected first, since detection of fraud is an important pre- requisite of rooting out its occurrence.

\section{Forensic Accounting and Fraud Detection}

It is agreeable that an auditor does not have the absolute duty to uncover fraud, but is expected to practice fair and true reporting to ensure that the interests of the public as well as the employees are protected (Enofe, Okpako, and Atube, 2013). Companies should look towards new approaches rather than follow the traditional approach as forensic accounting may be the next best alternative in resolving financial problems (Enofe, Okpako, and Atube, 2013).

Earlier research (Rezaee 2002; Crumbley 2003 and 2009; Peterson and Reider 1999, 2001; Rezaee, Reinstein, and Lander 1996; Rezaee and Burton 1997) reviews the literature on forensic accounting practices, certifications, and education. These studies also provide evidence indicating that forensic accounting education has evolved from being limited, to continuing professional education sessions for practicing accountants, to a current state of being offered as a credit course by several universities (Enofe, Okpako and Atube, 2013). (Buckhoff and Schrader, 2000) observed that the inclusion of forensic accounting as a course to the accounting curriculum can greatly benefit the three major stakeholders in accounting education namely, the academic institutions, students, and employers of accounting graduates. Empirical evidence from a study by Boritz, Kotchetova and Robinson (2008) confirms that forensic accountants could detect significantly higher number of fraud than auditors. Srivastava, Mock and Turner (2003) in their study found that forensic audit procedures significantly lowered fraud risks. Furthermore, research has also proven that proactive forensic data analysis using computer based sophisticated analytical tests can detect fraud that may remain unnoticed for years (Brown, Aiken, and Visser, 2007).

According to the US General Accounting Office (GAO) (1996), there is now a strong emphasis on fraud prevention and detection during statutory audits. The united states and international standards setters have 
increased the responsibility of auditors to consider the risks of fraud while conducting audits of financial statements. A study by Bierstaker, Brody and Pacini (2006) revealed the perception of accountants regarding fraud detection and prevention methods. The findings revealed that organizational use of forensic accountants was the least often resorted to but had the highest effectiveness ratings. This is similar to the findings of Ernst and Young (2003) worldwide fraud survey, which states that only $20 \%$ of organizations employed forensic accountants although the satisfaction level for their service was rated at $88 \%$ as against the use of statutory auditors. There is however a greater call for auditors to acquire forensic skills in the discharge of their duty. This call has been corroborated by Enyi (2009) who submits that all normal statutory audits should contain some elements of forensic enquiry as the evidence of fraudulent activities can be easily discovered if a thorough evaluation of the adequacy and compliance of the internal control mechanism is made. All these are aimed at fraud prevention and detection. This may not be achieved by an auditor without some understanding of forensic accounting methods (Effiong, 2012).

\section{Use and Effectiveness of Fraud Prevention and Detection Mechanisms}

Internal control systems have been described as the basic means of preventing and detecting fraud (Wells, 2008). However, Barra (2010) contends that what constitutes an effective internal control system is more of opinions that are based on definite knowledge established through research.

Moyes and Baker (2003) carried out a study on auditors belief about the fraud detection effectiveness of standard audit procedures. The result shows that out of the 218 standard audit procedures, 56 were considered more effective in fraud detection. The study further reveals that the most effective procedures were those that related to internal controls in terms of its existence and or strength.

Also, Bierstaker, Burnaby and Hass (2004) investigated the extent to which internal auditors used the perceived effectiveness of the various fraud prevention and detection mechanisms. The outcome of the study suggests that internal control review and improvement, operational audits and reference checks on employees were the commonly used mechanisms of fraud prevention and detection, yet software and digital analysis with generally high ratings of effectiveness were the least often used.

ACFE (2008) has provided relevant findings regarding how fraud can be uncovered using the formal mechanisms such as internal audits and internal control features. Nevertheless, informal mechanisms have served as the most frequent precursor to fraud detection. About 42 per cent of fraud precursors have come through tips, 23 per cent through internal control, 20 per cent by accident and 19 percent by internal audit. External audit and the police account for about 9 and 3 percent respectively (ACFE, 2008; Drew and Drew, 2010) .

It has been argued that an effective internal control system is not protection against fraud (Blake, 2011). However, Muslimat and Hamid (2012) examined the role of internal audit in fraud prevention in government owned hospital in a Nigerian setting. Through survey research design, the study revealed that audit staff in the hospital lack the basic knowledge of fraud prevention, thereby making the hospital to be more prone to fraudulent practices. While the study reveals that audit staff tried to prevent some fraud incidences in the hospital, the auditors however believed that if better knowledge is acquired, the unit could perform better. This implies that, internal control do not deter fraudsters from committing fraud. Moreover, accounting literature has accepted the fact that the effectiveness of internal control system can be weakened by collusion (Barra and Griggs, 2007). Therefore, the need for the understanding of forensic accounting technique cannot be over emphasized.

\section{Basic skills of Forensic Accountants}

Thereare numerous opinion on the skills a forensic accountant should have. Harris and Brown (2000) while investigating the qualities of a forensic accountant identifies specialized skills and abilities that should be possessed by experts of their nature. They discovered that a forensic accountant should be conversant with civil and criminal law.

Also, they stressed the need for understanding of court room procedures and expectations, investigative skills, creative thinking as well as clear and precise communication skills.

According to Grippo and Ibex (2003), the most important skills of a forensic accountant arise from experience in accounting, internal controls, auditing, taxation management, interpersonal relationships, business operations and communication.

A set of competencies required by a forensic accountant have been identified by DiGabriele (2009). These skills include deductive analysis ability, creative thinking skill, unstructured problem solving competence, investigative flexibility, and analytical proficiency including oral communication ability, written communication ability, specific legal knowledge and good composure.

In a study conducted by Davis, Farrell and Ogilby (2010), on the features and skills of a forensic accountant; the views of attorneys, academics and CPAs were sought on the basic skills that a forensic accountant should possess. The results arrived at showed that a forensic accountant should be analytical, detailed 
- oriented, ethical, responsive, insightful, persistent and sceptic.

Ghosh and Banerjee (2011) identified three fold- approach of skills required by a forensic accountant to include the base, middle and top layer. The base layer comprises mainly accounting knowledge. The middle layer has to do with knowledge in the fields of auditing, internal controls, risk assessment and fraud detection. While at the top layer a strong knowledge of the legal environment is required including a strong communication skill. Based on their research, a forensic accountant is expected to have competence in a broad spectrum of disciplines including accounting, law, auditing, criminology, information technology and communication skills.

Knowledge and skills required in forensic accounting include the following:

Investigative skills, research, law, quantitative methods, finance, auditing, accounting, and law enforcement officer insights (Hopwood, Leiner and Young,(2012).

Hence, a forensic accountant must have deep analytical ability, develop critical thinking, knowledge and skills in organizational behaviour and applied psychology.

\section{7. $\quad$ Forensic Accountant Versus Traditional Accountant}

The forensic accountant applies reliable principles and methods to sufficient facts or data and typically needs expertise and skills in private investigation and accounting, while on the other hand, there is no such necessity in the traditional accounting space (Hopwood, Leiner and Young, 2012).

Forensic accountants share some goals similar to traditional accountants though they have different roles, knowledge and skills. Moreover, traditional auditing has a focus on error identification and prevention while forensic accounting involves fraud identification (Gray, 2008).

The standards of forensic accounting evolves from courts of law while those of traditional accounting like financial accounting are set by the Securities and Exchange Commission (SEC) for corporations whose securities such as common stock are exchanged (Gray, 2008).

Traditional auditing makes use of techniques of sampling to discover unintentional errors usually caused by weaknesses in internal controls which occur at regular intervals. On the other hand, intentional errors (fraud) by humans can only occur in few transactions, hence forensic accounting methods use full populations where possible (Albrecht and Albrecht, 2002). As a result of large volume of data that are required for forensic analysis, it is usually done with computer with the WorldCom fraud discovery being a typical example of detection using computer technology (Lamoreaux, 2007).

A forensic accountant carries out investigation on specific allegations. Hence, he has much time to investigate and analyse thoroughly specific fraudulent financial issues with emphasis of using such as evidence in a law court in case of dispute (Albrecht and Albrecht, 2009), while the audit carried out by a traditional auditor is general in nature. According to Milucky and Mac (2013), a traditional audit is carried out on general financial matters (that means the auditor considers all issues relating to accounting).

A forensic accountant is employed or appointed by organizations to resolve allegations and detect or prevent fraudulent activities suspected or envisaged in the organization. Thus, it is not a normal audit but audit which may or may not follow auditing procedures. Zimbleman et al. (2012) states that, such audit is a proactive audit which goes beyond normal audit procedures. A traditional auditor or statutory auditor is appointed to carry out statutory audit.

The audit is usually carried out to satisfy statutory requirements and ensure that accounts prepared are in line with GAAP. Millichamp (1990), state that the statutory audit is a compulsory audit which ensures that financial statements are in line with GAAP. From the foregoing, it can be deduced that a statutory auditor may not go beyond the procedural audit since he is not compelled by law to search for fraud but rather in carrying out it's audit function if fraud is detected he will unveil it.

\section{Responsibilities of a Forensic Accountant in Combating Fraudulent Activities}

A forensic accountant should perform the following responsibilities as listed below:

\subsection{Conducting Investigation}

Owojori and Asaolu (2009), state that the failure of the statutory audit and the sophisticated financial fraud in recnt times had led to the need for forensic audit.

Thus, the forensic accountant could be said to have special tools for conducting investigation as to detect and prevent fraudulent activities thereby combating financial fraud. Zimbleman (1997), states that a forensic accountant being a fraud investigator is very much likened to a physician who requires significant amount of diagnostic and explanatory work to discover what really is happening. In view of the above, it can be said that a forensic accountant goes beyond the normal audit as to unveil fraudulent activities by using forensic software tools in conducting and investigating transactions and events. 


\subsection{Analysing Financial Transactions}

Cole (2009), states that a forensic accountant is required to have special skills in inspecting documents for authenticity, alteration, forgery or counterfeiting. Hence, by possessing such skills, the forensic accountant in carrying out his duties can easily detect errors, fraudulent activities and omissions thereby preventing and reducing fraudulent activities. According to Zimbleman et al. (2012), a forensic accountant is responsible for analyzing and identifying the kinds of fraud that could occur and their symptoms.

\subsection{Reconstruction of Incomplete Accounting Records}

A forensic accountant in carrying out his function reconstructs incomplete accounting records to settle for example insurance claims, over inventory valuation, proving money laundering activities by reconstructing cash transactions (Owojori and Asaolu, 2009).

8.4 Embezzlement Investigation

Cabole (2009), states that a forensic accountant does the following:

- Fraud detection, documentation and presentation in criminal trails and claims.

- Calculate economic damages, trace income and assets, often in an attempt to find hidden assets or income.

- Reconstruction of financial statements that may have been destroyed or manipulated.

- $\quad$ Expert witness.

The above responsibilities listed by Cabole (2009) shows that a forensic accountant must be an expert in financial matters and must have legal knowledge which could enable him detect fraudulent activities which are to be presented in a law suit.

\section{Challenges of Forensic Accounting Application in Nigeria}

Enyi (2009) undertook a study to offer suggestions using real case problem on how to apply forensic accountingin investigating variances and suspected fraudulent activities in manufacturing processes and thus suggests that the application of forensic accounting applies to all scenes where fraud is a possibility.

Crumbley (2001), Grippo and Ibex (2003), reveal the following challenges confronting the application of forensic accounting.

i. A significant challenge that faces a forensic accountant is the task of gathering information that is admissible in a court of law.

ii. The admissibility of evidence in compliance with the laws of evidence is crucial to successful prosecutions of criminal and civil claims

iii. Globalization of the economy and the fact that a fraudster can be based anywhere in the world has led to the problem of inter-jurisdiction.

Degboro and Olofinsola (2007) noted that an important challenge to the application of forensic accounting in Nigeria is that the law is not always up to date with the latest advancements in technology. Also, forensic accounting is seen as an expensive service that only big companies can afford. Thus, most companies prefer to settle the issue outside the court to avoid the expensive cost and the risk of bad publicity on their corporate image. In additions, forensic accounting is a new trend particularly in developing economies. Hence, accountants with adequate technical know-how on forensic issue are hardly available.

\section{Importance of A Forensic Accountant}

The importance of forensic accountants can be clearly understood from the context of failure in statutory audits to detect and prevent fraud as summarized by Owojori and Asaolu (2009). A forensic accountant can be relevant in the following ways:

10.1Assist Police Force in Investigation

A forensic accountant engages himself in criminal investigation on behalf of police force (Eiya and Otalor, 2013), where his report is prepared with the objective of presenting evidence in a professional and concise manner.

10.2 Improve Management Accountability

Ramaswany (2009) states that failure of corporate communication structure has made the financial community realize that there is a great need for skilled professionals that can identify, expose and prevent weaknesses in three key areas: poor corporate governance, flawed internal controls, and fraudulent financial statement. Forensic accounting skills are becoming increasingly relied upon within a corporate reporting system that emphasizes its accountability to stakeholders. From the abovestatement, a forensic accountant with his expert knowledge in crime will help to improve corporate reporting system designed by management which will expose and prevent poor governance, flawed internal control and fraudulent financial statement. 
10. 3Strengthen Auditors Independence

Most times external auditors are afraid to report cases of fraud committed by management to the stakeholders even when such frauds are obvious. This impairs the independence of the auditor who is afraid to lose his job since most times they are appointed by management who prepares accounts that is being audited (Albrecht and Denn, 2001). According to Albrecht (2001), improving financial reporting system with expertise knowledge and skill in both financial matters, the forensic financial reporting system through use of proactive method of fraud detection have strengthened external auditors independence.

\section{4Assist Audit Committee Members}

Forensic accountants assist audit committee members in carrying out oversight functions by providing better tools that ensures that quality assurance audit report have been produced by the external auditor. According to Zimbelman et al (2012), a forensic accountant in carrying out his responsibilities of controlling fraudulent activities use data driven fraud detection tool which is proactive unlike the traditional approach which is reactive and is been adopted by the external auditor in carrying out statutory audit functions.

10.5Helping in Detecting Fraud

With the use of analytical and technological skills, a forensic accountant can easily detect financial fraud perpetrated by management thereby preventing corporate failure. Cleary and Thibodeous (2005), states that the forensic accountant knows how to detect and prevent business fraud using Benford law (a fraud analytical digital tools). Hence, it could be said that a forensic accountant in helping to detect and prevent fraudulent activities could be seen to have helped organizations in reducing financial fraud which most times had led to corporate collapse.

\section{Instances of Using Forensic Accountants in Nigeria}

Enyi (2009) applied a combination of simple auditing techniques of internal control evaluation tests on randomly selected significant transactions, simple accounting ratio analysis and simple variance analysis to arrive at clues which pointed out the true direction to follow in an investigation to uncover series of fraudulent activities that were concealed on incremental basis over a period of four years in a Nigeria based company's financial statement.

The instance of forensic investigation was able to provide an accounting analysis that revealed the whole extent to which fraudulent activities in the buying and production division affected the company's fortunes over the stated period.

The main points of the analysis became the main evidence with which the police was able to arrest and prosecute the perpetrators of the fraud, the outcome to which was an out of court settlement between the company and those accused.

Also, recent forensic audit of the Nigeria Stock Exchange (NSE) by commissioned group of independent auditors has revealed shady deals in the expenses of the exchange which were not discovered during statutory audits (Nweke, 2010).

Okoye and Gbegi (2013) examined forensic accounting as a tool for fraud detection and prevention in public sector organizations. Their study was conducted with reference to Kogi State in Nigeria. Data for the study were obtained from both the primary and secondary sources. 370 copies of the research questionnaire were administered to staff of five selected ministries in the state with 350 copies properly filled and returned. This quantitative method of data collection was complimented with oral interviews. It was discovered that the use of forensic accountants will significantly reduce the occurrence of fraud cases in the public sector. However, it was discovered that Kogi State does not use the services of forensic accountants.

\section{Conclusion and Recommendation}

The role of a forensic accountant under contemporary conditions no doubt is very important because they help lawyers, courts, the police, regulatory bodies and other institutions in investigating and documenting frauds. The increasing occurrence of fraud in modern day business environment requires the services of forensic accountants to unearth fraudulent activities within and outside an organization. Also, continued audit failures over the last five decades have prompted a paradigm shift in accounting. It is generally accepted that an auditor has the duty to perform tests to detect material defalcation and errors if they exist. However, fraud detection experts called forensic accountants are now been hired in developed economies to investigate cases of fraud.

Therefore, it is recommended that professional bodies in Nigeria like the Institute of Chartered Accountants, Association of National Accountants, and the National Universities Commission should encourage the formalization and specialization in the field of forensic accounting.

In addition, government should develop more interest in forensic accounting for monitoring and 
investigating suspected culprits in fraud cases as evidenced in the examples earlier cited. Also, our laws should be up to date with latest advancement in technology to ensure admissibility of evidence in a law court for successful prosecution of criminal and civic cases. Government should have an effective plan with other countries in extraditing run away fraudsters from anywhere around the globe. Finally, it is also recommended that government should ameliorate the expenses involved in engaging the services of a forensic accountant.

It is hoped that if these recommendations are implemented and culprits treated without favouritism; the occurrence of fraud will reduce drastically within the Nigerian Society which ultimately should impact on our global rating by transparency international.

\section{References}

Adeniji, A.A. (2004). Auditing and Investigation, (Lagos): Value Analyst Consult.

Ajie, H.A., \&Ezi, C.T. (2000).Financial Institutions and Markets.Owerri: Corporate Impression.

Albrecht, C.C. (2001). “Proactively Detecting Fraud”. (Financial Post, July 2001), 13- 15.

Albrecht, C.C. and Denn, J.G. (2001). Can Auditor Detect Fraud? (Dec. 2001), 213- 219.

Albrecht, W.S. and Albrecht, C.C. (2002). Root out Financial Deception. Journal of Accountants, pp. 30 - 33.

Albrecht, C.C. and Albrecht, C.O. (2009). "Datadrisen Fraud Detection Using Detectless".Journal of Forensic and Investigation Accounting, Vol. 1 No. 1, pp. 1 - 24.

Apostolou, B., Hassel, J.M., \& Webber, S.A. (2002).Forensic Expert Classification of Management Fraud Risk Factors.Journal of forensic Accounting, Vol. 1, 181 - 192.

Arokiasamy, L., \& Cristal- Lee, S. (2009). Forensic Accounting: Public Acceptance Towards Occurence of Fraud Detection. International Journal of Business and Management. Pp. 144-160.

Associate of Certified Fraud Examiners (2008). Report to the Nation on Occupational Fraud Abuse. Austine, Tx: Association of Certified Fraud Examiners.

Association of Certified Fraud Examiner (2012). Report to the Nation on Occupational Fraud and Abuse. Austine, Tx; Association of certified Fraud Examiners.

Ayanwu, J.C. (1993). Monetary Economics: Theory, Policy and Institution, (Onitsha): Hybrid.

Barra, R.A. and Griggs, K. (2007). Internal Control: Lessons to be Learned from Fire. International Journal of Services and Standards, 3 (4), pp. 375 - 389

Baird, J.E., \&Zelin, R.C. (2009). An Examination of the Impact of Obedience Pressure on Perceptions of Fraudulent Acts are the Likelihood of Committing Occupational Fraud. Journal of Forensic Studies.Accounting Business.

Barra, R.A. (2010). The Impact of Internal Controls and Penalties on Fraud.Journal of Information Sysytems, 24 (1), pp. 1-21.

Blake, H.M. (2011). Report of the Auditor - General Special Report No. 95 Fraud Control; Tasmanian Audit Office.Available from: www.audit.tas.gov.au/publications/reports/specialreport/index.htm.[Accessed: 25/06/2015].

Bierstaker, J.L., Burnaby,P. and Hass, S. (2004). Internal Auditors Fraud Prevention and Detection Methods. Internal Auditing, 19.3 (May/June), Pp. $37-40$

Bierstaker, J.L., Brody, R.G., \&Pacini, C. (2006).Accountants Perceptions Regarding Fraud Detection and Prevention Methods.Managerial Auditing Journal, 21(5), 520 - 535.

Boritz, J.E., Kotchetova, N., \& Robinson, L.A. (2008). Planning Fraud Detection Procedures: forensic Accountants $\quad \mathrm{V}_{\mathrm{s}}$ Auditors. [Available at http://aaahq.org/meetings/AUD2009/PlanningFraudDetectionProcedures. pdf].

Brown, R.G. (1962). Changing Audit Objectives and Techniques. Accounting Review 37, No. 4 (October): 696 $-703$.

Brown, A., Aiken, P., \&Visser, L. (2007). Reducing Fraud: A Programme that will Deliver Benefits on the Bottom Line. Accountancy (Ireland), 39(6), $28-30$.

Buckhoff, T.A. \& Schrader, R.W. (2000).The Teaching of Forensic Accounting.Journal of Forensic Accounting, 1(1), $135-146$.

Cabole (2009), Forensic Accounting: A paper presented at the (Hilton Hotel Lagos), Certified Public Accountant (CPA) Journal New York Accessed Online file: //c:/user/document/Accessed on 20/6/2015.

Chary, T.S. (2005). How Forensic Accounting can Check Corporate ills. The Chartered Accountant, pp. 10401043.

Clearing,R. and Thibodeous, C.(2005), Applying Digital Analysis Using Benfords Law to Detect Fraud. Journal of Practice and Theory, pp. 77-81

Cole (2009).Forensic Audit, Paper presented at Hilton Hotel Lagos 2/06/09. [Accessed:30/06/2015].

Crumbley, D.L. (2001). Forensic Accountants: Older than You Think. Journal of Forensic Accounting, 2(2),Pp. 181-202.

Crumbley, D.L. (2003). What is Forensic Accounting? Forensic Accounting: Older than You Think. Journal of 
Forensic Accounting, 11 (2), 181-202. Retrieve from: www.edwardpub.com

Crumbley, D.L., Heitger, L.E., \& Smith, G.S.(2005). Forensic and Investigative Accounting.CCH Group, (Chicago, IL.)

Crumbley, D.L.(2009). So What is Forensic Accounting? The ABO Reporter fall (9).

Davis,C., Farrell, R., \&Ogilby, S. (2010). Characteristics and Skills of the Forensic Accountant.American Institute of Certified Public Accountants.

Degboro, D. and Olofinsola, J. (2007).Forensic Accountants and Litigation Support Engagement. Nigerian Accountant, 40(2), Pp.49-52

DiGabriele, J.A. (2009). Fishbowl the Forensic Accountant: A Closer Look at the Skills of Forensic Accounting Education should Emphasize. The Forensic Examiner, 18(2), Pp.77-79.

Drew, J.M. and Drew, M.E. (2010).Ponzimoniumi Madoff and the Red Flags of Fraud.Griffit Business School, University of Griffith Australia.

Effiong, E.J. (2012). Forensic Accounting Education: An Exploration of Level of Awareness in Developing Economics- Nigeria as a Case Study. International Journal of Business and Management, 7 (4), Pp.2634.

Eiya,O. and Otalor, J.I. (2013). Forensic Accounting as a Tool for Fighting Financial Crime in Nigeria. Research Journal of Finance and Accounting, 4(6), Pp. 18-25.

Enofe, A.O., Okpako, P.O., \&Atube, E.N. (2013).The Impact of Forensic Accounting on Fraud Detection.Journal of Business and Management, Vol. 5, No. 26.

Enyi, E.P. (2009). Detection Causes of Variances in Operational Outputs of Manufacturing Organization: A Forensic Accounting Investigation Approach. Retrieved from http:/ssrn.com/abstract=1144783 [Accessed 24/06/2015].

Ernst \& Young. (2003). Fraud: Unmanaged Risk. 8th Global Survey. Global Investigations Dispute Advisory Services, (South Africa).

General Accounting Office (1996). The Accounting Profession Major Issues: Progress and Concerns. (NewYork): GAO.

Ghosh, I. and Banergie, K.K. (2011). Forensic Accounting - Another Feather in that hat of Accounting. The Chartered Accountant, October, pp. $60-63$.

Gray, D. (2008). Forensic Accounting and Auditing: Compared and Contrasted to Traditional Accounting and Auditing. American Journal of Business Education, Forth Quarter, 1(2),pp. 115 - 126.

Gray, O.R. and Moussalli, S.D., Forensic Accounting and Auditing United Again: A historical perspective (2006). Journal of Business Issues, No.2, pp. 15-25, 2006. Available at SSRN: http//ssrn. Com/ abstract $=1642100$

Grippo, F.J. and Ibex, T. (2003).Introduction to Forensic Accounting. National Public accounting, 4, pp. $4-8$

Harris, C.K. and Brown, A.M. (2000).The Qualities of a Forensic Accountant. Pennsylvania CPA Journal, 71, pp. $2-3$

Hopwood, W.S., Leiner, J.J., and Young, G.R. (2012).Forensic Accounting and Fraud Examination. 20th ed. (New York): McGraw - Hill.

Karwai, S.A. (2002). Bank Fraud: Can ShariahPrevent it? Journal of Business Administration, 2(1), 62 - 78

Kasum, A.S. (2009). The Relevance of Forensic Accounting to Financial Crimes in Private and Public Sectors of Third World Economies: A study from Nigeria. In the $1^{\text {st }}$ International Conference on Governance Fraud Ethics and Social Responsibility (15 April, 2009).

Lamoreaux, M. (2007). Internal Auditor used Computer Tools to Detect WorldCom Fraud. Journal of Accountancy, 35.

Mehta, G.S. and Mathur, T. (2007). Preventing Financial FruadThrough Forensic Accounting. The Chartered Accountant, pp. $1575-1580$.

Millichamp, A.H. (1990). Auditing an Instructional Manual for Accounting Students, $4^{\text {th }}$ Edition,London DP Publications.

Milucky, J.J. and Mac, C. (2013).Forensic Accounting Specialist on Corporate Governance, the Role of the Auditors and the Legal Context.[Accessed: 26/06/2015].

Moyes, G. and Baker, C.R. (2003). Auditor's Belief About the Fraud Detection Effectiveness of Standard Audit Procedures. Journal Forensic Accounting, 4(2), pp. 199 - 216.

Modugu, K.P. andAnyaduba, J.O. (2013).Forensic Accounting and Financial Fraud in Nigeria.An Empirical Approach.International Journal of Business and Social Science, 4(7).

Muslimat, A. and Hamid, K.T. (2012). The Role of Internal Audit Unit in Fraud Prevention in Government Owned Hospitals in Nigeria. IOSR Journal of Business and Management, 2(5), pp. 39 - 44

Okafor, B. (2004). Strategic Approach to Reduction of Employee Theft Fraud and Embezzlement. Nigerian Accountant, 37(4), 3-5.

Okoye, E.I. and Gbegi, D.O. (2013). Forensic accounting: A Tool for Fraud Detection and Prevention in the 
Public Service. (A Study of Selected Ministries in Kogi State).International Journal of Academic Research in Business and Social Sciences, 3(3), pp. 1-18.

Owojori, A.A. and Asaolu, T.O. (2009). The Role of Forensic Accounting in Solving the Vexed problem of Corporate World. European Journal of Scientific Research, 29(2), pp. 183- 187.

Peterson, B.K., and Reider, B.P. (1999). Fraud Education of Accounting Students: A Survey of Accounting Educators. The National Accounting Journal, 23 - 30.

Peterson, B.K., and Reider, B.P. (2001).An Examination of forensic Accounting Courses Content and Learning Activities.Journal of Forensic. Accounting, 2(1), 25 - 42.

Rasey, M. (2009). History of Forensic Accounting. Retrieved from http://www.ehow.com/about _ 5005763 history_forensic_accounting. html..

Rezaee, Z., (2002). Forensic Accounting Practices, Education, and Certifications.Journal of Forensic Accounting, 3(2), $207-225$.

Ramaswany, V. (2009).Corporate Governance and the Forensic Accountant. The Certified Public Accountant (CPA) Journal, New York. [Accessed: 27/06/2015].

Rezaee, Z.Reinstein, A., and Lander, G.H. (1996).Integrating Forensic Accounting into the Accounting Curriculum.Accounting Education, 1(2), 147-162.

Rezaee, Z. and Burton, E.J. (1997).Forensic Accounting Education.Insights from Academicians and Certified Fraud Examiner Practitioners. Managerial Auditing Journal, 12(9), 479 - 489.

Singleton, T.W. and Singleton, A.J. (2010). Fraud Auditing and Forensic Accounting, the $4^{\text {th }}$ edition, New Jersey U.S.A. John Wiley and Sons Inc.

Srivastava, R.P., Mock, T.J., and Turner, J.L. (2003).The Effects of Integrity, Opportunity, Incentives, Militating factors and Forensic Audit Procedures on Fraud Risk.Business and Information Management Auditing Research Workshop, Australian National Universities.

Wells, J.T. (2008). Principles of Fraud Examination.Wiley, Hoboken, N.J.

Weygandt, J.J., Kieso, D.E., \& Kimmel, P.D. (2008). Accounting Principles, (8 ${ }^{\text {th }}$ ed.). Wiley Retrieved from http://www.kpmg. Co.uk/ news/detail.cfm? $\mathrm{Pr}^{1} / 43541$.

Zimbleman, M.K. (1997). The Effects of SAS No. 82 on Auditors Attention to Fraud Risk Factors and Audit Planning.Journal of accounting Research, (Supplement 1997), pp. 75 - 97.

Zimbleman, M.K., Albrecht, C.C., Albrecht, S.W. and Albrecht, C.O. (2012).Forensic Accounting, Cengage Learning, International edition Canada, $4^{\text {th }}$ Edition.Pg 429.

Zysman, A. (2004). Forensic Accounting Demystified: World Investigators Network Standard Practice for Investigative and Forensic Accounting Engagements, Canadian Institute of Chartered Accountants, (Nov. 2006). 
The IISTE is a pioneer in the Open-Access hosting service and academic event management. The aim of the firm is Accelerating Global Knowledge Sharing.

More information about the firm can be found on the homepage:

http://www.iiste.org

\section{CALL FOR JOURNAL PAPERS}

There are more than 30 peer-reviewed academic journals hosted under the hosting platform.

Prospective authors of journals can find the submission instruction on the following page: http://www.iiste.org/journals/ All the journals articles are available online to the readers all over the world without financial, legal, or technical barriers other than those inseparable from gaining access to the internet itself. Paper version of the journals is also available upon request of readers and authors.

\section{MORE RESOURCES}

Book publication information: http://www.iiste.org/book/

Academic conference: http://www.iiste.org/conference/upcoming-conferences-call-for-paper/

\section{IISTE Knowledge Sharing Partners}

EBSCO, Index Copernicus, Ulrich's Periodicals Directory, JournalTOCS, PKP Open Archives Harvester, Bielefeld Academic Search Engine, Elektronische Zeitschriftenbibliothek EZB, Open J-Gate, OCLC WorldCat, Universe Digtial Library, NewJour, Google Scholar

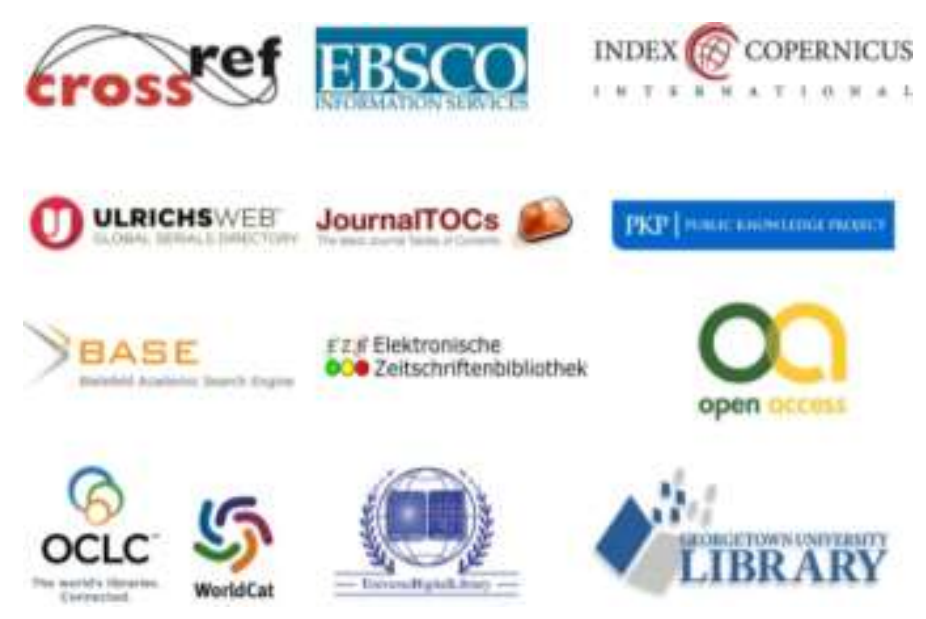

